\title{
Antimicrobial Peptides: A Wide Range of Novel Compounds and Their Role as Plant Defense Peptides
}

\author{
Mansi Srivastava* \\ Department of Biochemistry and Biochemical Engineering, Sam Higginbottom, India
}

Received: December 11, 2017; Published: January 03, 2018

*Corresponding author: Mansi Srivastava, Ph.D in Biochemistry, Department of Biochemistry and Biochemical Engineering, Sam Higginbottom University of Agriculture, Technology and Sciences, Allahabad, India; Email: mansisrivastava27@gmail.com

\begin{abstract}
Plant antimicrobial peptides have been identified and isolated from a wide variety of species. These are defensins, lipid transfer proteins, havein and knottin like peptides and cyclotides. They consist of various protein groups with different features like overall charge of the molecules, the amount of disulphide bonds and the structural stability under environmental stress. The three-dimensional structures of several classes of plant antimicrobial peptides have been well studied but the mechanism of action of some of these compounds is still not well understood. This mini review focuses on the features and properties of the antimicrobial peptides in plants.
\end{abstract}

\section{Introduction}

Despite their sedentary lifestyle plants share some common aspects in their defense mechanisms against pathogens. These features are small peptides that have antimicrobial properties which is part of more ancient and widespread defense strategy in all organisms. These are a product of single gene that can be synthesized in a swift and flexible way, due to their small size they can be produced by host with minimal input of energy and biomass. Well known examples of antimicrobial peptides are cecropins that accumulate in the hemolymph of many invertebrates in response to injury or infection [1] and other example are magainins that are secreted by glands in the skin of amphibians [2].

\section{Plant Defence Peptides}

Antimicrobial peptides have long considered playing a key role in plant defense, both as a part of pre-existing, developmentally regulated defense barriers and as part of defense responses that occur upon infection. The antimicrobial peptides in animals may be linear or more complex globular structures in which antiparallel $\beta$ - sheet are stabilized by disulphide bonds. But in plants only disulphide bonded peptides of second type have been identified till now [3]. The first antibacterial peptide isolated from a plant species was a purothionin from wheat flour (Triticum aestivum), which has the ability to inhibit the growth of some phytopathogens such as Pseudomonas solanacearum, Xanthomonas campestris and Cornybacterium michiganense [4]. Almost 40 years later, several additional peptides with antibacterial activity have been characterized, represented not only by thionins, now named defensins, but also by other groups of proteins such as cyclotides, glycine- rich proteins, snakins, $2 \mathrm{~S}$ albumins and hevein-type proteins [5]. Peptides isolated from roots, seeds, flower, stem and leaves have shown activities towards pytopathogens as well as against bacteria pathogenic to humans. Over the last decade, antimicrobial peptides have become an interesting tool for the development of techniques in the control of crop loses and in the production of novel antibiotics for the treatment of various human infections [6,7].

\section{Conclusion}

Antibacterial peptides have described in a variety of plant species. They belong to a vast range of protein families. Some peptides show specificity towards gram-positive or gram - negative bacteria, but most of them are able to inhibit the activity of both. The study of their mechanism of action shows that these antibacterial peptides are involved in strong interaction with phospholipids from pathogen's membrane. Parameters such as a molecular volume, aggregation ability and auto assembly on the membrane surface are critical for activity against bacteria. Although, the mode of action of these antibacterial peptides is well characterized, investigations on the importance of specific amino acid residues and their binding with the bacterial cell wall are still in progress.

\section{Acknowledgement}

The author is grateful to Dr. (Mrs.) Sushma Ahlawat, Assistant professor, Sam Higginbottom University of Agriculture, Technology \& Sciences (SHUATS), Allahabad, India, for her kind support towards this study. 


\section{References}

1. Boman HG, Hultmark D (1987) Cell free immunity in insects. Annu Rev Microbiol 41: 103-126.

2. Bevins CL, Zasloff M (1990) Peptides from frog skin. Annu Rev Biochem 59: 395-414.

3. Hultmark D (1993) Immune reactions in Drosophila and other insects: a model for innate immunity. Trends Genet 9: 178-182.

4. Caleya RF, Gonzalez-Pascual B, García-Olmedo F, Carbonero P (1972) Susceptibility of phytopathogenic bacteria to wheat purothionins in vitro. Appl Microbiol 23: 998-1000.
5. Selitrennikoff CP (2001) Antifungal Proteins. Appl Environ Microbiol 67: 2883-2894.

6. Tam JP, Lu YA, Yang JL, Chiu KW (1999) An unusual structural motif of antimicrobial peptides containing end-to-end macrocycle and cystineknot disulfides. Proc Natl Acad Sci of the United States of America 96: 8913-8918.

7. Pelegrini PB, Murad AM, Silva LP, Dos Santos RC, Costa FT, et al. (2008) Identification of a novel storage glycine-rich peptide from guava (Psidium guajava) seeds with activity against Gram-negative bacteria. Peptides 29: 1271-1279.

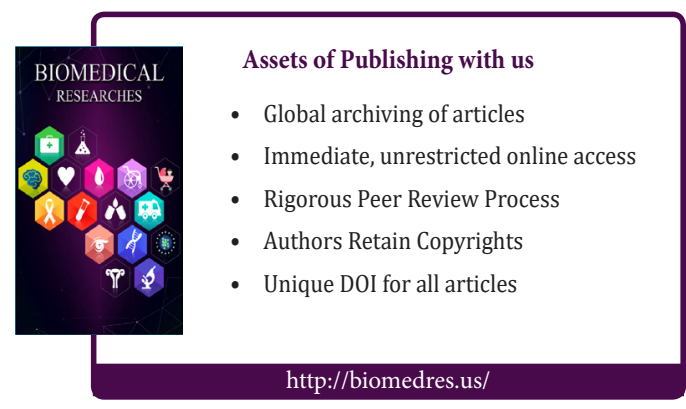

